\title{
Evaluation of Complete Blood Count Parameters for Diagnosis in Children with Sepsis in the Pediatric Intensive Care Unit
}

\author{
Pediatrik Yoğun Bakım Ünitesinde Sepsisli Çocuklarda Tanı İçin \\ Tam Kan Sayımı Parametrelerinin Değerlendirilmesi
}

\author{
Fatih Aygün'(iD), Cansu Durak'(ID), Fatih Varol'(ID), Haluk Çokuğraş²(iD), Yıldız Camcıoğlu²(i D), Halit Çam¹(ID) \\ ${ }^{\prime}$ Department of Pediatric Intensive Care, Istanbul University School of Cerrahpasa Medicine, Istanbul, Turkey \\ 2 Department of Pediatric Infectious Diseases, Istanbul University School of Cerrahpasa Medicine, Istanbul, Turkey
}

Cite this article as: Aygün F, Durak C, Varol F, Çokuğraş H, Camcıoğlu Y, Çam H. Evaluation of complete blood count parameters for diagnosis in children with sepsis in the pediatric intensive care unit. J Pediatr Inf 2020;14(2):e55-e62.

\begin{abstract}
Objective: Early diagnosis of sepsis is important for effective treatment and improved prognosis. C-reactive protein (CRP) and procalcitonin (PCT) are the most commonly used biomarkers for sepsis. However, their routine usage is not cost-effective. Complete Blood Count (CBC) parameters including red cell distribution width (RDW), neutrophil to lymphocyte ratios (NLR), platelet to lymphocyte ratios (PLR), mean platelet volume (MPV), and hemoglobin are simple and easily calculated. The aim of this study was to determine the CBC parameters in patients with sepsis on admission and compare with those of the control group.
\end{abstract}

Material and Methods: The medical records of 115 eligible patients (68 sepsis, 47 control patients) who were hospitalized in PICU between January 2014 and March 2019 were retrospectively investigated. Demographic, prognostic and laboratory findings of the patients admitted with sepsis were compared with those of the control patients.

Results: Sixty-eight (59.1\%) of the patients were admitted with sepsis, severe sepsis or septic shock. In sepsis patients, CRP ( $p<0.001)$, leukocyte count $(p=0.004)$, MPV $(p<0.001)$, RDW $(p<0.001)$ were higher and platelet count $(p=0.016)$ was lower than the control group, the difference was statistically significant. Analysis of ROC curves showed that CRP, at a cut off value $0.66 \mathrm{mg} / \mathrm{dL}$, had a sensitivity of $82.4 \%$ and a specificity of $70.2 \%$. RDW showed $76.5 \%$ sensitivity and $76.6 \%$ specificity (cut off: $14.55 \%$ ); hemoglobin showed $83.0 \%$ sensitivity and $72.3 \%$ specificity (cut off: 10.9 $\mathrm{g} / \mathrm{dL}$ ). Correlation analysis showed positive correlation between sepsis and CRP $(r=0.627, p<0.001)$ and RDW $(r=0.585, p<0.001)$, and a negative correlation with hemoglobin $(r=-0.562, p<0.001)$. In logistic regres-
Öz

Giriş: Erken tanı sepsiste etkili tedavi ve iyi prognoz için önemlidir. C-reaktif protein (CRP) ve prokalsitonin (PKT) sepsiste en sık kullanılan biyobelirteçlerdir. Fakat rutinde kullanımı maliyet etkin değildir. Tam kan sayımı (TKS) parametrelerinden eritrosit dağılım genişliği (EDG), nötrofil lenfosit oranı (NLO), trombosit lenfosit oranı (TLO), ortalama trombosit hacmi (OTH) basit ve kolay olarak hesaplanmaktadır. Bu çalışmanın amaCI sepsisli hastalarda başvurudaki TKS parametrelerinin incelenmesi ve kontrol grubu ile karşılaştırılmasıdır.

Gereç ve Yöntemler: Ocak 2014-Mart 2019 tarihleri arasında çocuk yoğun bakım ünitesinde yatırılan çalışma için uygun olan 115 (68'i sepsis, 47'si kontrol) hastanın tıbbi kayıtları geriye dönük olarak incelendi. Sepsis tanısı ile başvuran hastaların demografik, prognostik ve laboratuvar bulguları kontrol hastaları ile karşılaştırıldı.

Bulgular: Altmış sekiz (\%59.1) hasta sepsis, ağır sepsis veya septik şok tanılarıyla başvurmuştu. Sepsisli hastalarda kontrol grubuna göre CRP $(p<0.001)$, lökosit sayısı $(p=0.004)$, OTH $(p<0.001)$, EDG $(p<0.001)$ daha yüksek, trombosit sayısı $(p=0.016)$ daha düşüktü, aralarındaki fark istatistiksel olarak anlamlıydı. ROC eğrisi analizi sonucunda CRP için kesme değeri $0.66 \mathrm{mg} / \mathrm{dL}$ olup \%82.4 duyarlı ve \%70.2 özgüldü. EDG için duyarlılık \%76.5, özgüllük \%76.6 (kesme değeri: \%14.55), hemoglobin için duyarlılık \%83.0, özgüllük \%72.3 (kesme değeri: 10.9 g/dL) idi. Korelasyon analizi sonucu sepsis ile CRP $(r=0.627, p<0.001)$ ve EDG $(r=0.585$, $p<0.001)$ arasında pozitif, hemoglobin $(r=-0.562, p<0.001)$ ile negatif yönlü bir korelasyon saptandı. Lojistik regresyon analizinde, EDG'nin her bir sayısal artışı sepsis olma olasılığını 2.094 kat arttırmaktadır.

\author{
Correspondence Address/Yazışma Adresi \\ Fatih Aygün \\ İstanbul Üniversitesi Cerrahpaşa Tıp Fakültesi, \\ Çocuk Yoğun Bakım Bilim Dalı, \\ İstanbul-Türkiye \\ E-mail: faygun9@hotmail.com
}


sion analysis, each numerical increase of RDW increases the probability of having sepsis by 2.094 fold.

Conclusion: Admission RDW, MPV, platelet, and hemoglobin values are related with sepsis in the PICU. These parameters are cost effective, useful, and easily accessible tests for diagnosing sepsis in critically-ill children. However, RDW alone may not provide sufficient evidence for the diagnosis of sepsis.

Keywords: Hemoglobin, neutrophil/lymphocyte ratio, red distributions width, mean platelet volume, sepsis, procalcitonin, C-reactive protein

\section{Introduction}

Accurate and early diagnosis is important to initiate effective treatment and improve the prognosis of sepsis. Therefore, a large number of biomarkers have been developed for the diagnosis of sepsis. Unfortunately, none of these biomarkers exhibit a high degree of sensitivity and specificity. The most common of these markers is C-reactive protein (CRP), which is a major acute-phase reactant in infection and inflammation (1). Another important biomarker of sepsis is procalcitonin (PCT). PCT levels are undetectable in the plasma of healthy people and increases in serious bacterial infections (2). Interleukin-6 (IL6), which is a cytokine released during inflammatory processes, is an another commonly used biomarker (3). However, routine measurements of these biomarkers are not cost effective.

Recent literature focuses on $\mathrm{CBC}$ parameters that are easy to evaluate and routinely analyzed. White blood cell (WBC), neutrophil $(\mathrm{N})$, lymphocyte $(\mathrm{L})$, platelet counts, neutrophil to lymphocyte ratios (NLR), red cell distribution width (RDW), hemoglobin, mean platelet volume (MPV), and platelet to lymphocyte ratios (PLR) are low-cost and easily calculated CBC tests. Since these parameters are affected by many inflammatory conditions, there are various studies regarding the importance of $C B C$ parameters in the prognosis of sepsis. Herein, we aimed to evaluate the possible association between early diagnosis of sepsis and CBC parameters in a PICU.

\section{Materials and Methods}

\section{Study Design}

Healthcare provision for children aged from 1 month to 18 years is provided in our PICU, which is equipped with 7 beds, 7 ventilators, and 2 isolation rooms. The data of all patients $(n=$ 607) admitted to the PICU for various critical illnesses between January 2014 and March 2019 were extracted from electronic and written medical records (in accordance with the ethical principles for medical research), and included in this study. Patients with a history of PICU stay duration of $<24 \mathrm{~h}$ and those who died on the first day of admission were excluded. In addition, patients with metabolic, rheumatologic, hematologic and oncologic diseases were excluded since they could change the results. The patients were included in our study provided that they had sepsis at admission.
Sonuç: Başvuru EDG, OTH, trombosit ve hemoglobin değerleri çocuk yoğun bakım ünitesinde sepsis ile ilişkilidir. Bu parametreler kritik hasta çocuklarda sepsis teşhisi için uygun maliyetli, kullanışı ve kolay erişilebilir testlerdir. Fakat EDG tek başına sepsis tanısı için yeterli olmayabilir.

Anahtar Kelimeler: Hemoglobin, nötrofil lenfosit oranı, eritrosit dağılım hacmi, ortalama trombosit hacmi, prokalsitonin, C-reaktif protein

The study was conducted in accordance with the Declaration of Helsinki, and informed consent was obtained from parents or legal guardians of the patients when they were admitted to the PICU. The local ethics committee (Ethical committee, no: 29430533-903.99-109967, December 13, 2018) approved the study.

We have recorded all materials, data, computer codes, and protocols associated with the publication for readers.

\section{Patient Population and Data Collection}

Demographic data, reason for hospitalization, underlying chronic diseases, and initial CBC and CRP were recorded. For CBC measurements, peripheral blood was collected using an EDTA vacutainer tube and analyzed with an automated blood cell counter (Cell-Dyn 3700, USA). NLR ratio and PLR were calculated as the ratio of neutrophils to lymphocytes and platelets to lymphocytes, respectively.

Age, sex, invasive or noninvasive mechanical ventilation, inotropic drugs, blood component transfusions, continuous renal replacement therapy (CRRT), intensive care duration, the pediatric risk of mortality (PRISM) score, and laboratory findings at admission were accepted as possible risk factors of sepsis, and they were recorded (Table 1). The demographic, prognostic, and laboratory findings of patients admitted with sepsis were compared to patients with control patients. We used patients who were admitted for drug intoxications as controls. These patients were taken as the control group considering that there would be no change on admission blood values. There was no hematological drug intoxication in these patients.

Ninety-five (15.6\%) of the patients in this study were diagnosed with sepsis. Twenty-seven of them were excluded because of underlying diseases and hospitalization time. Forty-seven of the 607 patients were admitted to the PICU with the diagnosis of drug intoxication. The remaining 47 patients with intoxication had no previous history of any chronic disease. Thus, 68 sepsis and 47 control patients were included in the study (Figure 1). None of the patients in the intoxication group developed sepsis or nosocomial infection after hospitalization. The prognostic and laboratorial differences between the groups were examined. 
Table 1. Demographic and clinical characteristics of patients with sepsis admitted to the pediatric intensive care unit from January 2014 to March 2019

\begin{tabular}{|c|c|}
\hline Parameters & $\begin{array}{c}\mathrm{n}=68(\%), \text { or median } \\
(\text { min-max })\end{array}$ \\
\hline $\begin{array}{l}\text { Sex } \\
\quad \text { Male } \\
\text { Female }\end{array}$ & $\begin{array}{l}31(45.6 \%) \\
37(54.4 \%)\end{array}$ \\
\hline $\begin{array}{l}\text { Infection origin } \\
\text { Respiratory system } \\
\text { Digestive system } \\
\text { Urinary } \\
\text { Central nervous system } \\
\text { Others (catheter related etc.) }\end{array}$ & $\begin{array}{c}30(44.1 \%) \\
12(17.6 \%) \\
7(10.3 \%) \\
8(11.8 \%) \\
11(16.2 \%)\end{array}$ \\
\hline $\begin{array}{l}\text { Pathogens } \\
\text { Klebsiella pneumoniae } \\
\text { Neisseria meningitidis } \\
\text { Escherichia coli } \\
\text { Staphylococcus aureus } \\
\text { Streptococcus pneumoniae } \\
\text { Others } \\
\text { Cultures negative }\end{array}$ & $\begin{array}{c}10(14.7 \%) \\
7(10.3 \%) \\
7(10.3 \%) \\
4(5.9 \%) \\
2(2.9 \%) \\
10(14.7 \%) \\
28(41.2 \%) \\
\end{array}$ \\
\hline Body temperature $\left({ }^{\circ} \mathrm{C}\right)$ & $37.0(33-39)$ \\
\hline Age of patients (years) & $1.1(1 \mathrm{mo}-17.8 \mathrm{y})$ \\
\hline Acute kidney injury & $39(57.4 \%)$ \\
\hline Inotropic drug administration & $40(58.8 \%)$ \\
\hline Continuous renal replacement treatment & $15(22.1 \%)$ \\
\hline Mechanical ventilation application & $37(54.4 \%)$ \\
\hline Red blood cell transfusion & $54(79.4 \%)$ \\
\hline Length of PICU stay (day) & 7.0 (26h-97d) \\
\hline PRISM III score & $12.0(2-42)$ \\
\hline Mortality & $13(19.1 \%)$ \\
\hline NIV application & $34(50.0 \%)$ \\
\hline Plasma exchange & $10(14.7 \%)$ \\
\hline
\end{tabular}

The following parameters were covered as determined by the PRISM III scoring system (4):

- Cardiovascular system, including systolic blood pressure and heart rate,

- Nervous system, including pupils' light reflex and level of consciousness,

- Blood tests, including arterial blood gas $\left(\mathrm{pH}\right.$, total $\mathrm{CO}_{2^{\prime}}$ $\mathrm{PaO}_{2}$ and $\mathrm{PaCO}_{2}$ ), serum levels of sugar, blood urea nitrogen and creatinine, platelet and white blood cell counts, prothrombin time and partial thromboplastin time,

- Body temperature.

Patients with sepsis/septic shock were enrolled in the study using criteria according to the Surviving Sepsis Campaign guidelines (5).
We defined acute kidnet injury (AKI) as oliguria (urine output of $<0.5 \mathrm{~mL} / \mathrm{kg} / \mathrm{h}$ for $6 \mathrm{~h}$ ) and an elevated serum creatinine value for the patient's age or a 1.5-fold increase in the creatinine concentration at $24 \mathrm{~h}$ (relative to admission). The estimated glomerular filtration rate was calculated according to the original Schwartz formula, based on serum urea and creatinine concentrations that were measured using standard laboratory procedures.

\section{Define of Pediatric Sepsis and Severe Sepsis}

Sepsis was the SIRS induced by infection, severe sepsis was the organ dysfunction or tissue hypoperfusion caused by sepsis, septic shock was tissue hypoperfusion and cardiac dysfunction caused by sepsis. SIRS was the presence of at least two of the following four criteria, one of which must be abnormal temperature or leukocyte count (6).

1. Core temperature of $>38.5^{\circ} \mathrm{C}$ or $<36^{\circ} \mathrm{C}$,

2. Tachycardia (HR $>2 S D$ above normal for age) or, for children $<1$-year-old, bradycardia ( $\mathrm{HR}<10^{\text {th }}$ percentile for age),

3. Tachypnea (RR $>2$ SD above normal for age),

4. Leukocyte count elevated or depressed for age or $>10 \%$ bands.

\section{Patient Statistical Analysis}

Statistical analysis was performed using IBM SPSS Statistics (Windows Version 21.0. Armonk, NY: IBM Corp.). Continuous variables were presented as median (with range) and categorical variables as frequencies (with percentages). Chisquare test was applied to calculate differences between groups. Normal distribution of continuous data was tested by Kolmogorov Smirnov test as our study sample size was greater than 30 . Significance value was $<0.05$ for most of the demographic and prognostic factors in this test. Therefore, we compared the continuous variables using Student's t-test and Mann-Whitney U-test for parametric and non-parametric data, respectively. Receiver operating characteristic (ROC) curve was used to assess the performance of sepsis markers. Sensitivity, specificity, positive and negative predictive values were calculated using previously described methods (7). Spearman test was used to correlate sepsis with RDW, CRP, hemoglobin and other markers. In our study, $r$ value inferior to 0.3 represents weak, values in between 0.3 and 0.7 represent strong and values above 0.7 represent very strong correlation (8). Multivariate binary logistic regression models were used to calculate the relationship between blood parameters and septic patients reported as ORs and $95 \% \mathrm{Cl}$. For all tests, $p<0.05$ was considered to be statistically significant. 


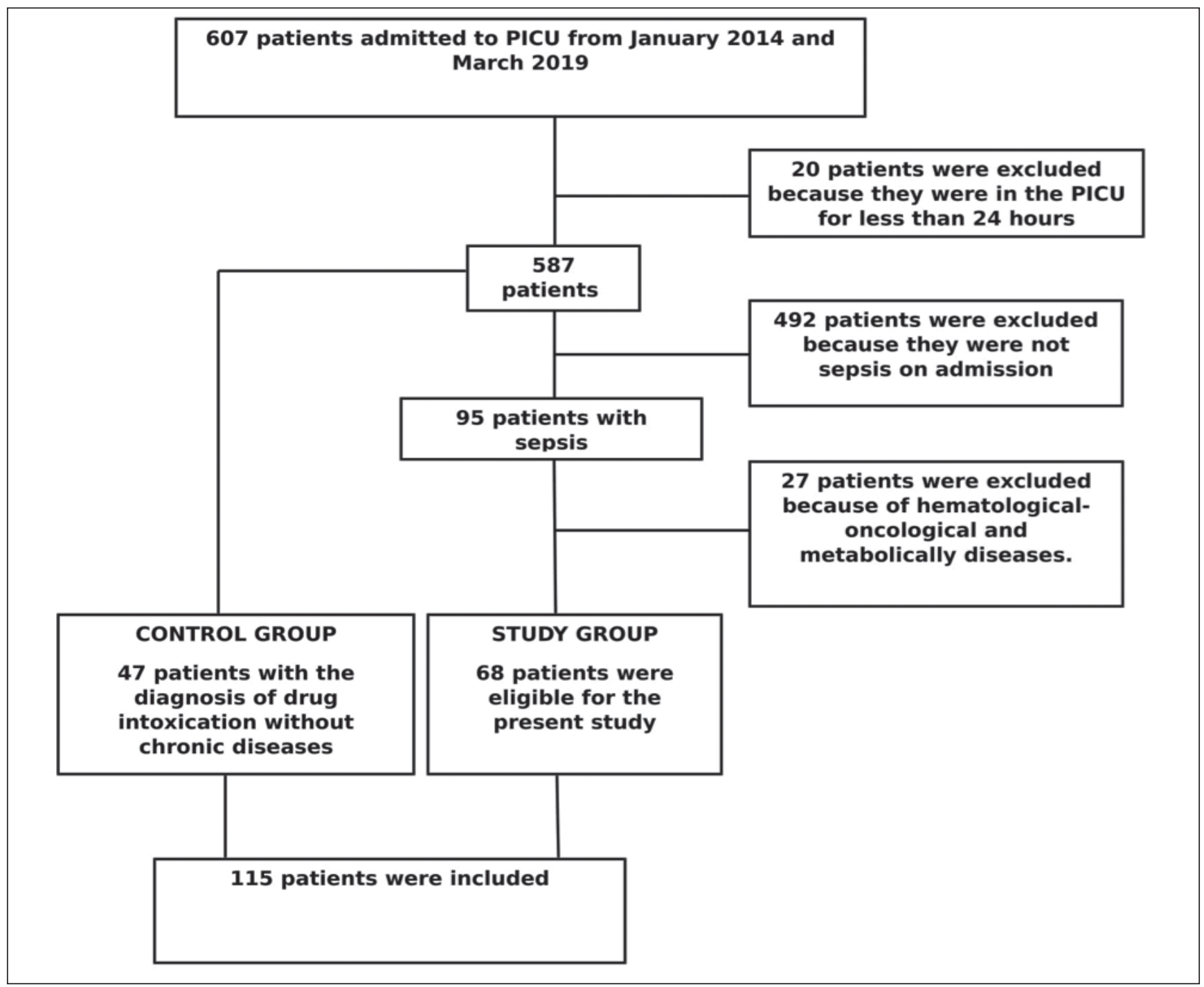

Figure 1. Cohort flow.

\section{Results}

\section{Demographics}

Between January 2014 and March 2019, 607 children were admitted to the pediatric intensive care unit (PICU). A hundred and fifteen patients were eligible for the present study (Figure 1).

There were 68 patients with sepsis: 31 (45.6\%) were males, $37(54.4 \%)$ were females. Their ages ranged between 1 month and 17.8 years, with a median of 1.1 years. The most frequent infection origins were respiratory system $(n=30,44.1 \%)$ and digestive system ( $n=12,17.6 \%)$. The most common microorganisms isolated from the cultures were Klebsiella pneumoniae (10 patients), Neisseria meningitidis (7 patients), and Escherichia coli (7 patients) (Table 1). Mean duration of hospitalization in the PICU was 7.0 days ( $26 \mathrm{~h}-97 \mathrm{~d}$ ) in the patients with sepsis (Table 2).

\section{The Prognostic Factors Associated with Sepsis}

There was a statistically significant relationship between sepsis and prognostic factors including WBC $(p=0.004)$, platelet count $(p=0.016)$, neutrophil count $(p=0.003)$, PRISM-III score $(p<0.001), \operatorname{RDW}(p<0.001), M P V(p<0.001), \operatorname{CRP}(p<$ $0.001)$, alanine transaminase (ALT) $(p=0.032)$, aspartate aminotransferase (AST) $(p=0.047)$, total serum bilirubin $(p<0.001)$, direct serum bilirubin $(p<0.001)$, duration of stay in the PICU $(p<0.001)$, and mortality $(p<0.001)$. There were no statistically significant differences with regard to sex, age, neutrophil count, lymphocyte count, NLR, and PLR in the PICU (Table 2).

\section{Analysis of Biomarkers By ROC Analysis in Sepsis and Control (Intoxication) Patients}

Analysis of ROC curves showed that CRP, at a cut-off value of $0.66 \mathrm{mg} / \mathrm{dL}$, had a sensitivity of $83.4 \%$ and a specificity of $73.2 \%$. Hemoglobin showed $83.0 \%$ sensitivity and $72.3 \%$ 
Table 2. Laboratory and prognostic factors associated with sepsis and without sepsis

\begin{tabular}{|c|c|c|c|c|}
\hline & Total $(n=115)$ & Sepsis patients $(n=68)$ & Control patients $(n=47)$ & $p$ \\
\hline Sex (male)* & $51(44.3 \%)$ & $31(45.6 \%)$ & $20(42.6 \%)$ & 0.747 \\
\hline Age $($ years)** & $1.1(1 \mathrm{mo}-17.8 \mathrm{y})$ & $4.7(1 \mathrm{mo}-17.8 \mathrm{y})$ & $6.0(1.0-17.0)$ & 0.092 \\
\hline \multicolumn{5}{|c|}{$\begin{array}{l}\text { MPV: Mean platelet volume, RDW: Red cell distribution width, ALT: Alanine aminotransferase, AST: Aspartate aminotransferase, PRISM: Pediatric risk of mortality, PICU: } \\
\text { Pediatric intensive care unit. } \\
\text { *Values are given as percentage. } \\
\text { ** Values are given as median (minimum-maximum). } \\
\text { *** Values are given as mean } \pm \text { standard deviation. }\end{array}$} \\
\hline
\end{tabular}

Table 3. Analysis of biomarkers using ROC curve in the patients for sepsis

\begin{tabular}{|c|c|c|c|c|c|c|c|c|}
\hline Parameter & Area under curve & SE & $\mathrm{p}$ & \multicolumn{2}{|c|}{$95 \% \mathrm{Cl}$} & Cut-off value & Sensitivity & Specificity \\
\hline PLR & 0.504 & 0.055 & 0.946 & 0.396 & 0.611 & 104.44 & $48.9 \%$ & $45.6 \%$ \\
\hline CRP & 0.868 & 0.032 & $<0.001$ & 0.805 & 0.931 & $0.66 \mathrm{mg} / \mathrm{dL}$ & $83.4 \%$ & $73.2 \%$ \\
\hline Leucocyte & 0.595 & 0.053 & 0.083 & 0.492 & 0.699 & $9900 \mu \mathrm{L}$ & $54.4 \%$ & $59.6 \%$ \\
\hline PLT & 0.653 & 0.052 & 0.006 & 0.552 & 0.755 & $265.000 \mu \mathrm{L}$ & $66.6 \%$ & $61.5 \%$ \\
\hline Neutrophil & 0.601 & 0.052 & 0.066 & 0.498 & 0.704 & $5950 \mu \mathrm{L}$ & $55.9 \%$ & $57.4 \%$ \\
\hline Lymphocyte & 0.501 & 0.055 & 0.982 & 0.393 & 0.609 & $1955 \mu \mathrm{L}$ & $47.1 \%$ & $55.8 \%$ \\
\hline MPV & 0.646 & 0.052 & 0.008 & 0.545 & 0.747 & $7.95 \mathrm{fL}$ & $60.3 \%$ & $66.0 \%$ \\
\hline
\end{tabular}

specificity (cut off: $10.9 \mathrm{~g} / \mathrm{dL}$ ); platelet count showed $66.6 \%$ sensitivity and $61.5 \%$ specificity (cut off: $265.500 / u L$ ); MPV showed $60.3 \%$ sensitivity and $66.0 \%$ specificity (cut off: 7.95 $\mathrm{fL}$ ); and RDW showed $76.5 \%$ sensitivity and $76.6 \%$ specificity (cut off: 14.55\%). Leucocyte counts, neutrophil count, lymphocyte count, NLR, and PLR showed low sensitivity and specificity (Table 3). The relationships between the biomarkers and sepsis are presented in Figures 2 and 3.

\section{Univariate Analysis of Sepsis and Risk Factors By Spearman's Correlation Analysis}

There were statistically significant positive correlations between sepsis and CRP $(r=0.627, p<0.001), \operatorname{RDW}(r=0.585, p<$ $0.001), \operatorname{MPV}(r=0.248, p<0.001)$, ALT $(r=0.351, p<0.001)$, AST $(r=0.364, p<0.001)$, direct bilirubin $(r=0.754, p<0.001)$, total bilirubin $(r=0.719, p<0.001)$, duration of stay in the PICU $(r=$ 


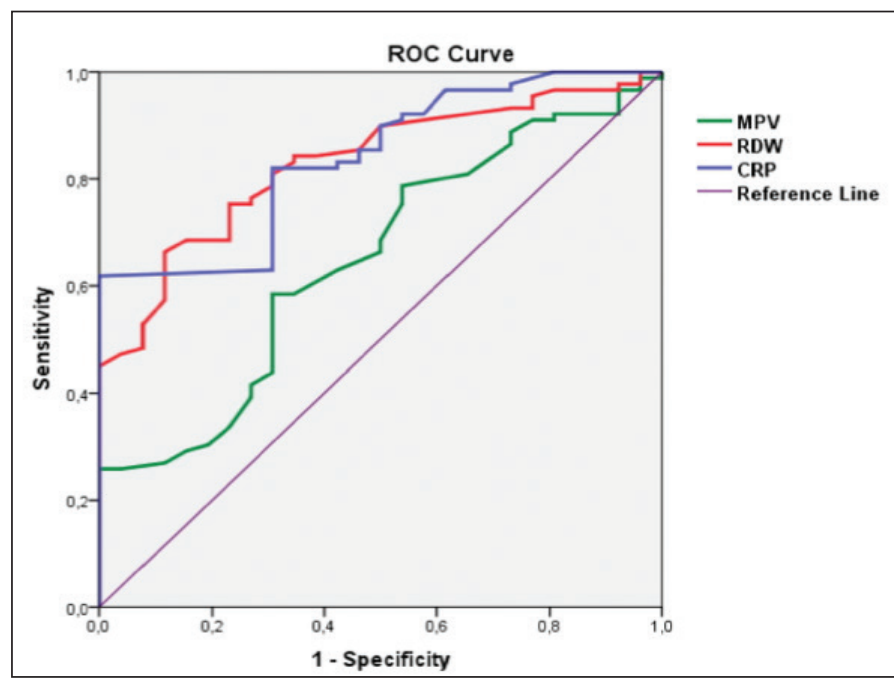

Figure 2. Analysis of ROC curves of correlation between sepsis and biomarkers (CRP, RDW, MPV).

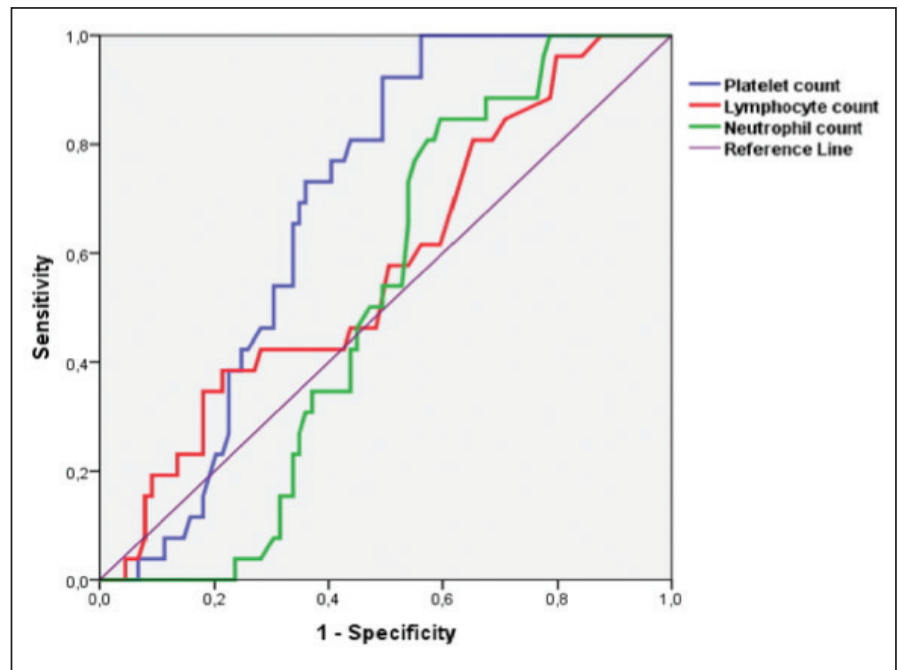

Figure 3. Analysis of ROC curves of correlation between sepsis and biomarkers (platelet, neutrophil, lymphocyte).

0.664, $p<0.001)$, and PRISM-III score $(r=0.732, p<0.001)$. In addition, there were statistically significant negative correlations between sepsis and platelet count $(r=-0.262, p=0.005)$, and hemoglobin $(r=-0.562, p<0.001)$ (Table 4).
Table 4. Correlation between sepsis and diagnostic markers in the study group

\begin{tabular}{|l|c|c|}
\hline \multirow{2}{*}{ Risk factors } & \multicolumn{2}{|c|}{ Sepsis } \\
\cline { 2 - 3 } & $\mathbf{r}$ & $\mathbf{p}$ \\
\hline C-reactive protein & 0.627 & $<0.001$ \\
Leucocyte count & 0.162 & 0.083 \\
Platelet count & -0.262 & 0.005 \\
Hemoglobin & -0.562 & $<0.001$ \\
Red cell distribution width (RDW) & 0.585 & $<0.001$ \\
Mean platelet volume (MPV) & 0.248 & 0.007 \\
Alanine aminotransferase (ALT) & 0.351 & $<0.001$ \\
Aspartate aminotransferase (AST) & 0.364 & $<0.001$ \\
Direct bilirubin & 0.754 & $<0.001$ \\
Total bilirubin & 0.719 & $<0.001$ \\
Duration of stay in the PICU & 0.664 & $<0.001$ \\
PRISM-III score & 0.732 & $<0.001$ \\
Platelet to lymphocyte ratio & 0.006 & 0.946 \\
Neutrophil to lymphocyte ratios & 0.045 & 0.418 \\
\hline PICU: Pediatric intensive care unit, PRISM: Pediatric risk of mortality.
\end{tabular}

\section{Logistic Regression Analysis of Risk Factors for RBC Transfusion}

The ORs and relationship between related parameters and sepsis were calculated using logistic regression models. ORs were $2.094(\mathrm{Cl}, 1.440-3.045)$ for RDW, $1.807(\mathrm{Cl}, 1.190-2.745)$ for CRP, $0.530(\mathrm{Cl}, 0.400-0.702)$ for hemoglobin, and $1.450(\mathrm{Cl}, 1.035-$ 2.031) for platelet count (Table 5). Each numerical increase of RDW increases the probability of having sepsis by 2.094 fold.

\section{Discussion}

In our study, it was found that hemoglobin, CRP, and RDW were useful tests for the diagnosis of sepsis in critically-ill children. When ROC analysis was performed, the most sensitive markers for sepsis were hemoglobin, CRP, and RDW. There was no significant association with sepsis in patients with PLR, NLR, leucocyte count, lymphocyte count when ROC analysis was performed. In addition, RDW, MPV, platelet count, hemoglobin, leucocyte count, liver function tests, and CRP levels were found to have correlated with sepsis.

Sepsis is a life-threatening syndrome affecting all age groups, having various complications, organ failure, and high mortality rates. Systemic inflammation in critical illness is com-

Table 5. Logistic regression analysis of the related parameters of sepsis in the PICU

\begin{tabular}{|l|c|c|c|}
\hline Risk & $\mathbf{p}$ & Odds ratio & $\mathbf{9 5 \%} \mathbf{C l}$ \\
\hline Red cell distribution width & $<0.001$ & 2.094 & $1.440-3.045$ \\
\hline Mean platelet volume & 0.319 & 1.205 & $0.835-1.737$ \\
\hline C-reactive protein & 0.006 & 1.807 & $1.190-2.745$ \\
\hline Hemoglobin & $<0.001$ & 0.530 & $0.400-0.702$ \\
\hline Platelet count & 0.031 & 1.450 & $1.035-2.031$ \\
\hline PICU: Pediatric intensive care unit. & & \\
\hline
\end{tabular}


monly associated with sepsis, leading to an increased risk of mortality. Since early diagnosis of sepsis is important, special biomarkers have been developed for diagnosing sepsis. C-reactive protein, PCT, WBC, and IL-6 are used as inflammatory biomarkers in many intensive care units $(3,9)$. CBC is an inexpensive, simple, routine, and repeatable test used to indicate the presence of infection. Leucocyte numbers and neutrophil ratios were the most commonly used indices for detecting infections. Recently, other CBC parameters, such as NLR and PLR have been used in children and adult patients for identifying inflammatory processes (10-12). These parameters are routinely measured in all patients admitted to the PICU. Additionally, NLR and PLR are more stable than other blood parameters and are less affected by fluid balance and laboratory techniques (13). Therefore, the relationship between NLR and PLR and was evaluated in sepsis patients in the present study.

Neutrophils are the first cellular elements of defense against infection, and lymphocytes are involved in the humoral-immune response. Depending on the level of inflammation, the number of neutrophils will increase, and the number of lymphocytes will decrease. When infection persists, large amounts of neutrophils are produced, so NLR increases as a result of these changes $(13,14)$. In the literature, elevated NLR levels have been associated with increased concentrations of various cytokines (15). In addition, some reports have shown a relationship between the NLR and PLR and adverse outcomes $(16,17)$. In another study, a large number of patients has been evaluated retrospectively to test the efficacy of CRP and CBC parameters as sepsis biomarkers. In that study, it has been shown that concomitant use of these biomarkers with mortality scores is more effective in the diagnosis of sepsis (18). In our study, NLR was not associated in sepsis patients, different from the literature. These studies have several differences from our study. The most important difference is that in these studies, the population included adult patients with underlying long-term chronic disease.

Recent studies have shown that PLR is elevated in various conditions. PLR has been associated with malignancy, acute appendicitis, acute kidney injury, and rheumatologic diseases in adult patients $(17,19)$. Cytokines released during infection can cause reactive thrombocytosis. As a result, PLR increases due to reactive thrombocytosis or lymphopenia (20). Studies regarding PLR in the prediction of sepsis are limited and have conflicting results. PLR has been described as an independent predictor of in-hospital mortality in patients with infective endocarditis (21). In our study, PLR was not associated with sepsis. In addition, ROC curve analysis showed that low AUC level between the sepsis and PLR. Like our study, Duman et al. have demonstrated no significant differences between the PLR levels of patients with sepsis, septic shock, and severe sepsis ( $p=$ $0.737)(22)$.

Serum CRP levels also increase markedly due to infections, inflammation, or tissue injury. In infections, the increase in CRP levels usually occurs after the rise in PCT (1). In our study, CRP was also associated with sepsis. ROC curves showed that CRP sensitivity and specificity was high. Gutiérrez et al. have reported that PCT and CRP levels could be used for the proper diagnosis and management of the early stages of sepsis (23). In our study, CRP was most sensitive and specific test for sepsis diagnosis. Previous studies about PCT have emphasized that PCT is more sensitive than CRP (24). PCT was not regularly used in our sepsis patients. Therefore, we could not include PCT level in our study. Spearman correlation analyze showed that there was a strong relationship between the CRP and sepsis in our study.

Thrombocytopenia is a common hematological finding in critically-ill patients. It is commonly associated with sepsis and disseminated intravascular coagulation (DIC). Studies have shown that a reduction in platelet counts is associated with prolonged hospitalization, increased costs, and mortality in adult populations $(25,26)$. In a large adult study, patients having the diagnosis of sepsis with thrombocytopenia at intensive care unit admission had a higher mortality score and increased mortality risk (27). In our study, we found a statistically significant relationship between sepsis and platelet count. The platelet count was significantly lower in the sepsis group. Differently, there was no relationship between PLR and sepsis.

In adult studies, it has been shown that RDW is an important predictor of sepsis diagnosis and prognosis, affecting mortality and intensive care unit stay $(28,29)$. In our study RDW was found as a favorable potential biomarker in diagnosis of sepsis. In addition, there was a strong correlation between RDW and sepsis.

The association of MPV with sepsis has been previously reported in the literature (30). In our study, significant correlation was found between MPV and sepsis. However, when this relationship was evaluated in the ROC curve and Spearman correlation analyze, it was seen that there was a weak relationship. We suggest that just MPV alone cannot be a sufficient marker for sepsis due to the weak correlation.

There was no significant relationship between sepsis and leukocyte count, whereas hemoglobin, MPV, platelet and RDW were associated with sepsis.

\section{Limitations of the Study}

There are some limitations of the present study. It is a retrospective single-centered study, and serial measurements of the biomarkers are missing. In addition, our study includes a limited number of patients. However, the comparison with other commonly used infection markers is the positive point.

\section{Conclusion}

This study demonstrated that admission CRP, RDW, hemoglobin values, and liver function test are associated with sepsis in the PICU strongly. CBC parameters are cost effective, useful, and easily accessible tests for the diagnosis of sepsis in critically-ill children. However, CBC parameters alone may not pro- 
vide sufficient evidence for the diagnosis of sepsis. Therefore, it would be more appropriate to use them with other infection markers.

Ethics Committe Approval: The local ethics committee (no: 29430533-903.99-109967, December 13, 2018) approved the study.

Informed Consent: Informed consent form was obtained from all patients.

Peer-review: Externally peer-reviewed.

Author Contributions: Concept - FA; Design - FA; Supervision - FA, $\mathrm{HÇ}$; Data Collection and/or Processing - FA, FV, CD; Analysis and/ or Interpretation - FA; Literature Review - FA; Writing - FA; Critical Reviews - FA, HÇ, YC.

Conflict of Interest: The authors have no conflicts of interest.

Financial Disclosure: Financial support was provided by departmental sources.

\section{References}

1. Lobo SM. Sequential C-reactive protein measurements in patients with serious infections: does it help? Crit Care 2012;16:130. [CrossRef]

2. Al-Nawas B, Shah PM. Procalcitonin, a new diagnostic and prognostic marker for severe infections. Clin Microbiol Infect 1998:4(5):237-41. [CrossRef]

3. Jekarl DW, Lee SY, Lee J, Park YJ, Kim Y, Park JH, et al. Procalcitonin as a diagnostic marker and IL-6 as a prognostic marker for sepsis. Diagn Microbiol Infect Dis 2013;75:342-7. [CrossRef]

4. Pollack MM, Patel KM, Ruttimann UE. PRISM III: an updated pediatric risk of mortality score. Crit Care Med 1996;24:743-52. [CrossRef]

5. Dellinger RP, Schorr CA, Levy MM. A users' guide to the 2016 surviving sepsis guidelines. Crit Care Med 2017;45(3):381-5. [CrossRef]

6. Goldstein B, Giroir B, Randolph A, International Consensus Conference on Pediatric Sepsis. International pediatric sepsis consensus conference: definitions for sepsis and organ dysfunction in pediatrics. Pediatr Crit Care Med 2005;6(1):2-8. [CrossRef]

7. Glas AS, Lijmer JG, Prins MH, Bonsel GJ, Bossuyt PM. The diagnostic odds ratio: a single indicator of test performance. J Clin Epidemiol 2003;56:1129-35. [CrossRef]

8. Akoglu H. User's guide to correlation coefficients. Turk J Emerg Med 2018;18(3):91-3. [CrossRef]

9. Vincent $J$ L, Beumier M. Diagnostic and prognostic markers in sepsis. EXpert Rev Anti Infect Ther 2013;11:265-75. [CrossRef]

10. Bekdas M, Goksugur SB, Sarac EG, Erkocoglu M, Demircioglu F. Neutrophil/lymphocyte and C-reactive protein/mean platelet volume ratios in differentiating between viral and bacterial pneumonias and diagnosing early complications in children. Saudi Med J 2014;35(5):442-7. [CrossRef]

11. Basaran O, Uncu N, Celikel BA, Aydın F, Cakar N. Assessment of neutrophil to lymphocyte ratio and mean platelet volume in pediatric familial Mediterranean fever patients. J Res Med Sci 2017;15:22-35. [CrossRef]

12. Bozdemir ŞE, Altıntop YA, Uytun S, Aslaner H, Torun YA. Diagnostic role of mean platelet volume and neutrophil to lymphocyte ratio in childhood brucellosis. Korean J Intern Med 2017;32(6):1075-81. [CrossRef]

13. Zahorec R. Neutrophil-to-lymphocyte ratio. Sixteen-year-long history since publication of our article in Bratislava Medical Journal. Bratisl Lek Listy 2017;118:321-3. [CrossRef]
14. Joshi VD, Kalvakolanu DV, Cross AS. Simultaneous activation of apoptosis and inflammation in pathogenesis of septic shock: a hypothesis. FEBS Lett 2003;555(2):180-4. [CrossRef]

15. Guthrie GJ, Charles KA, Roxburgh CS, Horgan PG, McMillan DC, Clarke SJ. The systemic inflammation-based neutrophil-lymphocyte ratio: experience in patients with cancer. Crit Rev Oncol Hematol 2013;88(1):218-30. [CrossRef]

16. Liu X, Shen Y, Wang H, Ge Q, Fei A, Pan S. Prognostic significance of neutrophil-to-lymphocyte ratio in patients with sepsis: a prospective observational study. Mediators Inflamm 2016;2016:8191254. [CrossRef]

17. Zheng CF, Liu WY, Zeng FF, Zheng MH, Shi HY, Zhou Y, et al. Prognostic value of platelet-to-lymphocyte ratios among critically ill patients with acute kidney injury. Crit Care 2017;21(1):238 [CrossRef]

18. Alan S, Tuna S, Türkoğlu EB. The relation of neutrophil-to-lymphocyte ratio, platelet-tolymphocyte ratio, and mean platelet volume with the presence and severity of Behçet's syndrome. Kaohsiung J Med Sci 2015;31:626-31. [CrossRef]

19. Gunduz S, Mutlu H, Tural D, Yıldız Ö, Uysal M, Coskun HS, et al. Platelet to lymphocyte ratio as a new prognostic for patients with metastatic renal cell cancer. Asia Pac J Clin Oncol 2015;11:288-92. [CrossRef]

20. Dame C, Sutor AH. Primary and secondary thrombocytosis in childhood. Br J Haematol 2005;129:165-77. [CrossRef]

21. Zencir C, Akpek M, Senol S, Selvi M, Onay S, Cetin M. Association between hematologic parameters and in-hospital mortality in patients with infective endocarditis. Kaohsiung J Med Sci 2015;31(12):632-8. [CrossRef]

22. Duman A, Akoz A, Kapci M, Ture M, Orun S, Karaman K, et al. Prognostic value of neglected biomarker in sepsis patients with the old and new criteria: predictive role of lactate dehydrogenase. Am J Emerg Med 2016;34:2167-71. [CrossRef]

23. Gutierez-Gutierrez B, Morales I, Perez-Galera S, Fernandez-Riejos P, Retamar $P$, de Cueto $M$. Predictive value of the kinetics of procalcitonin and C-reactive protein for early clinical stability in patients with bloodstream infections due to Gram-negative bacteria. Diagn Microbiol Infect Dis 2018;3S0732-8893(18)30256-6. [CrossRef]

24. Aygun F. Procalcitonin value is an early prognostic factor related to mortality in admission to pediatric intensive care unit. Crit Care Res Pract 2018;2018:9238947. [CrossRef]

25. Vandijck DM, Blot SI, De Waele JJ, Hoste EA, Vandewoude KH, Decruyenaere JM. Thrombocytopenia and outcome in critically ill patients with bloodstream infection. Heart Lung 2010;39:21-6. [CrossRef]

26. Khurana D, Deoke SA. Thrombocytopenia in critically ill patients: clinical and laboratorial behavior and its correlation with short-term outcome during hospitalization. Indian J Crit Care Med 2017;21(12):861-4. [CrossRef]

27. Claushuis TA, van Vught LA, Scicluna BP, Wiewel MA, Klein Klouwenberg PM, Hoogendijk AJ, et al. Thrombocytopenia is associated with a dysregulated host response in critically ill sepsis patients. Blood 2016;127(24):3062-72. [CrossRef]

28. Kim S, Lee K, Kim I, Jung S, Kim MJ. Red cell distribution width and early mortality in elderly patients with severe sepsis and septic shock. Clin Exp Emerg Med 2015;2(3):155-61. [CrossRef]

29. Han YQ, Zhang L, Yan L, Li P, Ouyang PH, Lippi G, Hu ZD. Red blood cell distribution width predicts long-term outcomes in sepsis patients admitted to the intensive care unit. Clin Chim Acta 2018;487:112-6. [CrossRef]

30. Oncel MY, Ozdemir R, Yurttutan S, Canpolat FE, Erdeve O, Oguz SS, et al. Mean platelet volume in neonatal sepsis. J Clin Lab Anal 2012;26:493-6. [CrossRef] 